УДК $631.4(470)$

\title{
ОРГАНИЧЕСКОЕ ЗЕМЛЕДЕЛИЕ В РОССИИ - БЛАГО ИЛИ КАТАСТРОФА?
}

\author{
К.Е. Стекольников \\ Воронежский государственный аграрный университет им. императора Петра I, Воронеж, Россия \\ Эл.noчma: soil@agrochem.vsau.ru \\ Статья поступила в редакцию 18.12.2019; принята к печати 02.03.2020
}

Органическое земледелие (О3), активно внедряемое в России, не может быть альтернативой интенсивному земледелию и не станет таковым из-за присущих ему нерешаемых проблем и несоблюдения законов земледелия. ОЗ не позволит соблюсти законы возврата, а его продуктивность будет ограничена законом минимума. ОЗ всегда будет сопровождаться дефицитом фосфора и калия. Внедрение О3 не только не обеспечит получение экологически «чистой» продукции, но и не способно произвести необходимое количество продукции для населения России. Утверждения приверженцев О3 о безопасности природных руд, которые предлагается использовать для компенсации выноса питательных элементов, не имеет оснований. Почему химический элемент из минерального удобрения опасен, а из природной руды- безопасен? Неужели так кардинально меняется природа и свойства химического элемента? Если следовать логике апологетов ОЗ, то это так. На синтез 1 моля азота симбиотические клубеньковые бактерии затрачивают 20,17 МДж, а технический азот получается при затратах 1,56 МДж, то есть он энергетически в 12,93 раза дешевле. Поэтому все рассуждения приверженцев ОЗ о «бесплатном» азоте безосновательны.

Ключевые слова: органическое земледелие, круговорот элементов питания, баланс элементов питания, биологический азот, энергетика биологической фиксаџии азота, плодородие почв, экологическая безопасность продукции.

\section{ORGANIC AGRICULTURE IN RUSSIA: A GOOD OR A DISASTER?}

\section{K.E. Stekolnikov \\ Emperor Peter the Great Voronezh State Agrarian University named after, Voronezh, Russia E-mail:soil@agrochem.vsau.ru}

Organic farming (OF), which is being actively introduced in Russia, cannot be an alternative to intensive agriculture and, because of its inherent unsolvable problems and non-compliance with the laws of agriculture, will not become such an alternative. OF will not provide for compliance with the Law of Return, and its productivity will be limited by the Law of Minimum. OF always will be accompanied by the shortage of phosphorus and potassium. OF introduction will not provide environmentally "clean" products. Moreover, it will be unable to produce enough products for the population of Russia. The claim of OF proponents that natural ores, which are supposed to compensate for nutrient removal, are safe is unsubstantiated. Indeed, why is a chemical element from a mineral fertilizer dangerous, whereas the same from a natural ore is safe? Can the properties of the element change so dramatically? They can, according to OF proponents logics, which thus denies the laws of Nature and science. The symbiotic rhizobia use $20.17 \mathrm{MJ}$ to produce one mole of nitrogen, whereas technical nitrogen is obtained at the cost of $1.56 \mathrm{MJ}$, i.e. the latter is 12.93 times cheaper in energy terms. Therefore, the argument that OF provides for "gratuitous" nitrogen is false.

Keywords: organic farming, nutrient cycle, nutrient balance, organic nitrogen, energy, biological nitrogen fixation, soil fertility, environmentally safe products.

Выдающийся мыслитель XVIII века Жан-Жак Руссо писал: «Единственное средство удержать государство в состоянии независимости... - это сельское хозяйство. Обладай вы хоть всеми богатствами мира, если вам нечем питаться, вы зависите от других. Торговля создает богатство, а сельское хозяйство обеспечивает свободу».

«Разве не поразителен факт, что в России, где такая масса роскошнейших земель, урожай наиболее распространенных хлебов - пшеницы, ржи и прочего - в два-три раза ниже, чем в Англии, Голландии, Бельгии, Франции и Германии. Неужели же мы никогда не примем действенных мер к устранению этого поразительного и крайне бедственного для России факта». Эти слова принадлежат В.В. Докучаеву - ученому, создавшему науку почвоведение. И сказаны они в далеком 1886 г. Прошло 130 лет, что изменилось? Ничего. Россия и в XXI веке продолжает так же отставать от развитых стран мира по урожайности сельскохозяйственных культур. Ах да, появилось «органическое земледелие».

13 мая 2017 г. Президент Российской Федерации поручил Правительству РФ до 15 июня внести в Госдуму проект федерального закона «О производстве и обороте органической продукции (продукции органического производства) и внесении изменений в отдельные законодательные акты Российской Федерации». Соответствующий Федеральный закон № 280-Ф3 от 3 августа 2018 г. вступил в силу с января 2020 г. В нем нет никаких особых требований, предъявляемых к качеству готового продукта. Речь идет лишь о способах производства.

Сертификация касается только производства органической продукции, а стандарты безопасности едины для любых пищевых продуктов. Трудно представить ситуацию, при которой на прилавках одни продукты будут безопаснее других. Когда на полке лежит упаковка фабричных яиц ценою 50-70 рублей, а рядом - упаковка яиц от производителя экологически 
«чистых» фермерских яиц за 280 рублей, кто может дать гарантию, что фермер не закупил партию фабричных яиц, удалил маркировку и выдал их за свой продукт? Карлу Марксу принадлежит фраза: «Ради получения 300\% выгоды капиталист зарежет собственную мать». Неужели природа человека настолько изменилась, что современный капиталист (или фермер) устоит перед соблазном получить 500\% прибыли? Автор в это не верит.

Возникает вопрос, откуда же свалилось это «благо»?

В первой четверти ХХ века австрийский родоначальник антропософии (греч. - «человеческая мудрость») Рудольф Штейнер (1861-1925) полагал, что от недостатков химизации человечество спасет «биодинамическое земледелие». Под этим земледелием понимается поддержание плодородия с помощью компостов, получаемых путем поливания куч растительных остатков фекалиями человека и домашних животных. В последующем эта идея переросла в направление «перманентная культура» (органическое земледелие).

Обратим внимание на то, что автор направления не призывал отказаться от минеральных удобрений, а предлагал только способ покрытия их дефицита. Изначально разумная идея была существенно извращена его последователями.

До 1940-х гг. органическое земледелие не тревожило головы людей. Во время Второй мировой войны в Англии государственные деятели развивали концепцию безминерального питания растений. Для этого была веская причина: шла война, а Великобритания - остров, находившийся в блокаде. Химия - только на нужды войны. Но и после войны продолжились теоретические и практические изыскания в сфере органического земледелия. Хотя, чему тут удивляться, даже алхимия продержалась несколько веков, и были люди, серьезно занимавшиеся ею.

В 1960-е гг. грянула «зеленая революция» - селекционеры создали сорта культур с удвоенной урожайностью. На волне этой революции поднялись вечно голодающие страны - Индия, Пакистан, Мексика и другие. В 1972 г. в Версале была основана Международная Федерация органического сельскохозяйственного движения (IFOAM) - бизнес, однако, и самый изуверский - без гарантий.

Цели весьма скромные - насадить свои идеи и завоевать весь мир. Смысл прост - органические «экологически чистые» овощи и фрукты просто обязаны стоить дороже, ибо важны человеческое здоровье, возврат к «истокам», чистая земля и многие другие блага. Да кто бы с этим спорил? Но ведь важен и способ достижения этого «блага», желательно честный и научно обоснованный. А вот с последним просто катастрофа. Вместо науки - заурядный обман.

Высокая стоимость органических продуктов обусловлена не их ценностью, а низкой эффективностью их выращивания. Большие объемы продукции невозможно получить органическими методами ведения хозяйства. Нужны дотации. И они в странах Европы есть. В частности, для производителей органических овощей размер субсидий составляет 625 евро/1 га, в Швейцарии один из самых высоких уровней субсидий, в то время как в Германии данный показатель равен в среднем 500 евро/га. Годовой размер государственных субсидий для производства продукции органического земледелия в Австрии - 600 млн евро. Дотации на 1 га при выращивании овощей - 800 евро/1 га, садов - 508 евро/1 га, пашни - 327 евро.

Ничего подобного нашим фермерам даже не снилось. Вот это и есть реалии органического земледелия.

Но есть еще одно обстоятельство, пожалуй, главное, весьма способствующее продвижению органического земледелия. Начиная с 1990-х годов во всем мире, и особенно в России, стремительно падает уровень образования. Образования общего, заставляющего людей думать и анализировать. Неграмотным населением управлять значительно проще, а значит, и донести до населения какую-либо идею не составляет особого труда. Ложь, повторенная многократно, превращается в правду, особенно для самих лгущих. В качестве наиболее убедительного аргумента для населения используется отсутствие пестицидов в «альтернативной» продукции и снижение загрязнения окружающей среды. Но где гарантия того, что в продукции нет остатков пестицидов, если сертифицируется способ производства, а не сама продукция? Приверженцы органического земледелия (см. например, [6]) оперируют мифами и передержками, и мы это докажем.

Миф № 1. Природа не пашет, и нам не надо.

Но ведь Природа и не убирает, у нее есть только биомасса, которая и остается на месте. А для людей нужен урожай, его надо вырастить, а для этого - посеять, а потом еще и убрать.

Масса трактора - 10-15 т, сеялки - 10-15 т, бункера с семенами и удобрениями - еще 3-5 т, и все это 25-35 т на колесах, по переувлажненной почве. На уборке сахарной свеклы работают только зарубежные комбайны, и очень хорошие. Но собственная масса комбайна немецкой фирмы Холмер с полным бункером - 54 т. То же и с зерноуборочными комбайнами. Дело в том, что масса комбайнов постоянно возрастает с увеличением их мощности и производительности. Масса комбайнов Ростсельмаш варьирует в пределах 11-15 тонн. При объеме бункера 5-7 м суммарная масса может превышать 16-22 т. У зарубежных комбайнов она еще выше, они и мощнее, и качественнее, но их масса с зерном достигает 30 т - как у танка 2-й мировой войны, но он на гусеницах.

Последствия известны - верхний слой почвы до глубины 0,5 м превращается в бетон (в сухом состоянии), а сама почва уплотняется на глубину до 1 м и более. Для того чтобы растения развивались нормально, требуется определенное соотношение между основными частями почвы: твердыми частицами, водой и воздухом. Оптимальной будет такая почва, в которой твердые частицы составляют 50\%, вода - 30 и воздух $-20 \%$. 
Если почва переуплотнена, урожайность резко снижается. Это объясняется тем, что переуплотненная почва плохо впитывает влагу. «Исследования американских специалистов показали, что уплотнение почв в основных зерносеющих районах США снижает урожай хлебов на 8-13\%. Во многих странах, в том числе и СССР, были поставлены специальные опыты. Они показали, что уплотнение пылевато-иловатого суглинка трактором, колеса которого давят на землю с силой 2 кг $/ \mathrm{cm}^{2}$, снижает урожайность картофеля более чем на 50\%. Имеются данные, что урожай заметно снижается, когда плотность

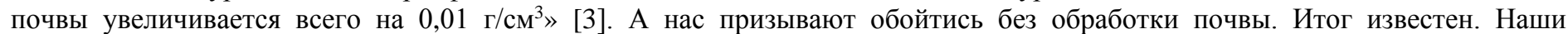
черноземы за последние 10-15 лет совершенно утратили зернистую структуру, это уже не черноземы.

Миф № 2. Органическое земледелие - самообеспечиваемая система.

А так ли это на самом деле?

Без вмешательства человека природная биосистема действительно замкнутая, самообеспечиваемая - никакого выноса из нее не происходит. Растения либо отмирают и разлагаются здесь же, либо возвращаются в почву через продукты жизнедеятельности животных.

Сельское хозяйство невозможно без выноса большей части биомассы с места произрастания. Желая регулярно получать урожаи, мы регулярно забираем органику и заключенные в ней элементы минерального питания.

Приверженцы органического земледелия игнорируют круговорот элементов питания и нарушение закона возврата. Ведь главное в органическом земледелии - это полный отказ от применения минеральных удобрений и химических средств защиты растений. Последнее мы не будем рассматривать, уделим основное внимание реализации полного отказа от минеральных удобрений. Возможен ли он без нарушения круговорота элементов питания и закона возврата? При ответственном отношении к проблеме ответ однозначен - невозможен. И это не голословное утверждение. Подтвердим это мнение расчетами.

Нами рассчитан баланс элементов питания за ротацию 6-польного севооборота в стационарном опыте [3]. Опыт был заложен на черноземе выщелоченном, малогумусном среднемощном тяжелосуглинистом в 1987 г. В опыте 15 вариантов. Для проведения исследований нами были выбраны следующие варианты опыта: 1 - контроль абсолютный, 2 - контроль фон (40 т/га навоза), 3 - фон + N60P60K60, 5 - фон + N120P120K120, 13 - фон + 21 т/га дефеката, 15 - дефекат + N60P60К60. 3десь цифры при обозначениях химических элементов означают их количество (т/га). Для расчетов мы учитывали вынос элементов питания с товарной и их возврат в почву с нетоварной частью сельскохозяйственных культур. Данные представлены на рис. 1 и 2.

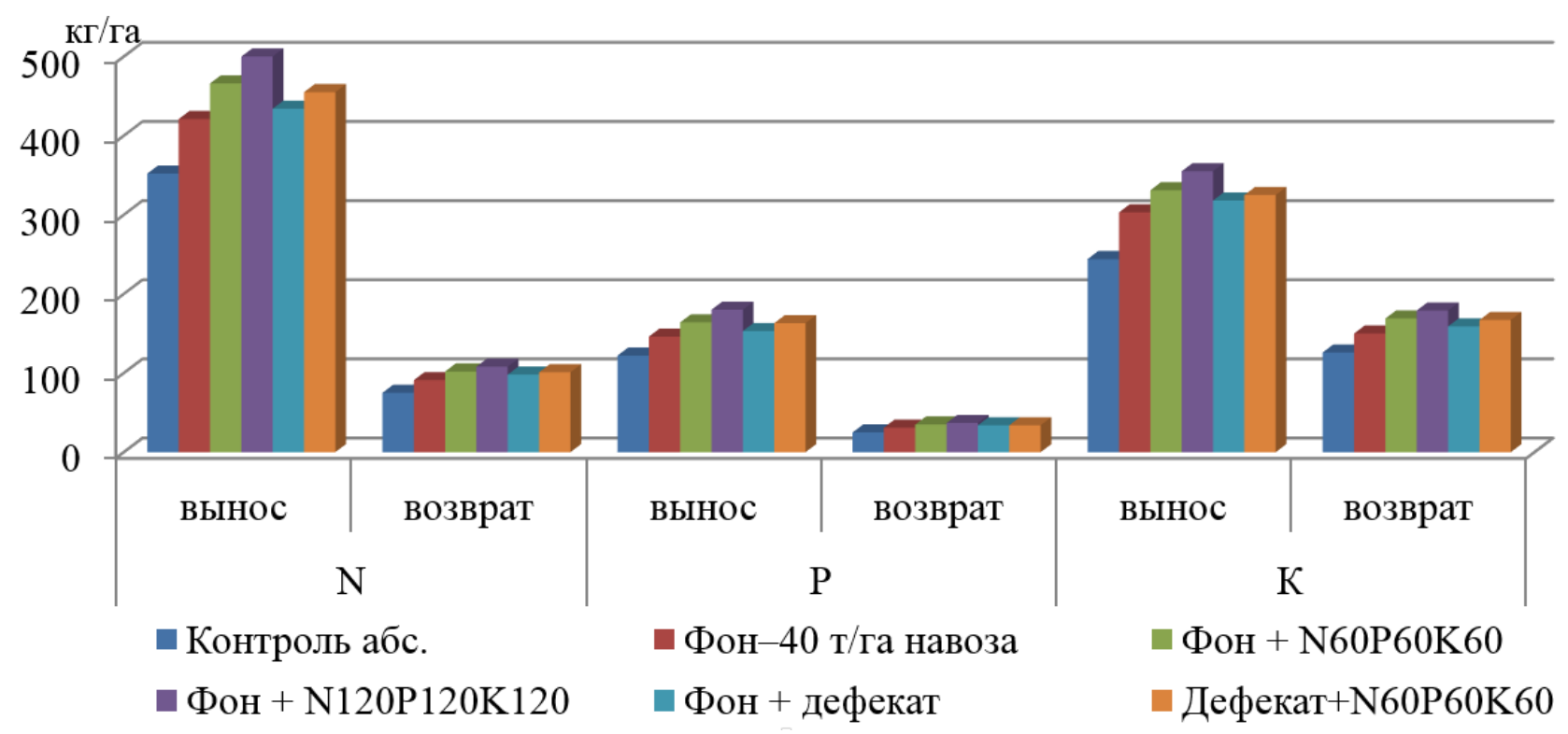

Рис. 1. Вынос и возврат элементов питания за ротацию севооборота (кг/га) [2]

Выбор 6 вариантов из 15 сделан для того, чтобы показать, как влияют системы применения удобрения на вынос и возврат элементов питания. Вариант 1 - экстенсивная система: удобрения не вносятся, урожай формируется за счет естественного плодородия. Вариант 2 - органическая система удобрения. Варианты 3, 5: одинарная (по 60 кг/га азота, фосфора и калия) и двойная доза (по 120 кг/га азота, фосфора и калия) минеральных удобрений по органическому фону органоминеральная система удобрения. 13 - дефекат (мелиорант для снижения кислотности почвы по органическому фону), 15 - дефекат совместно с одинарной дозой (по 60 кг/га азота, фосфора и калия). 
Как следует из рис. 1, вынос элементов питания с товарной частью сельскохозяйственных культур существенно превышает их возврат в почву с нетоварной продукцией.

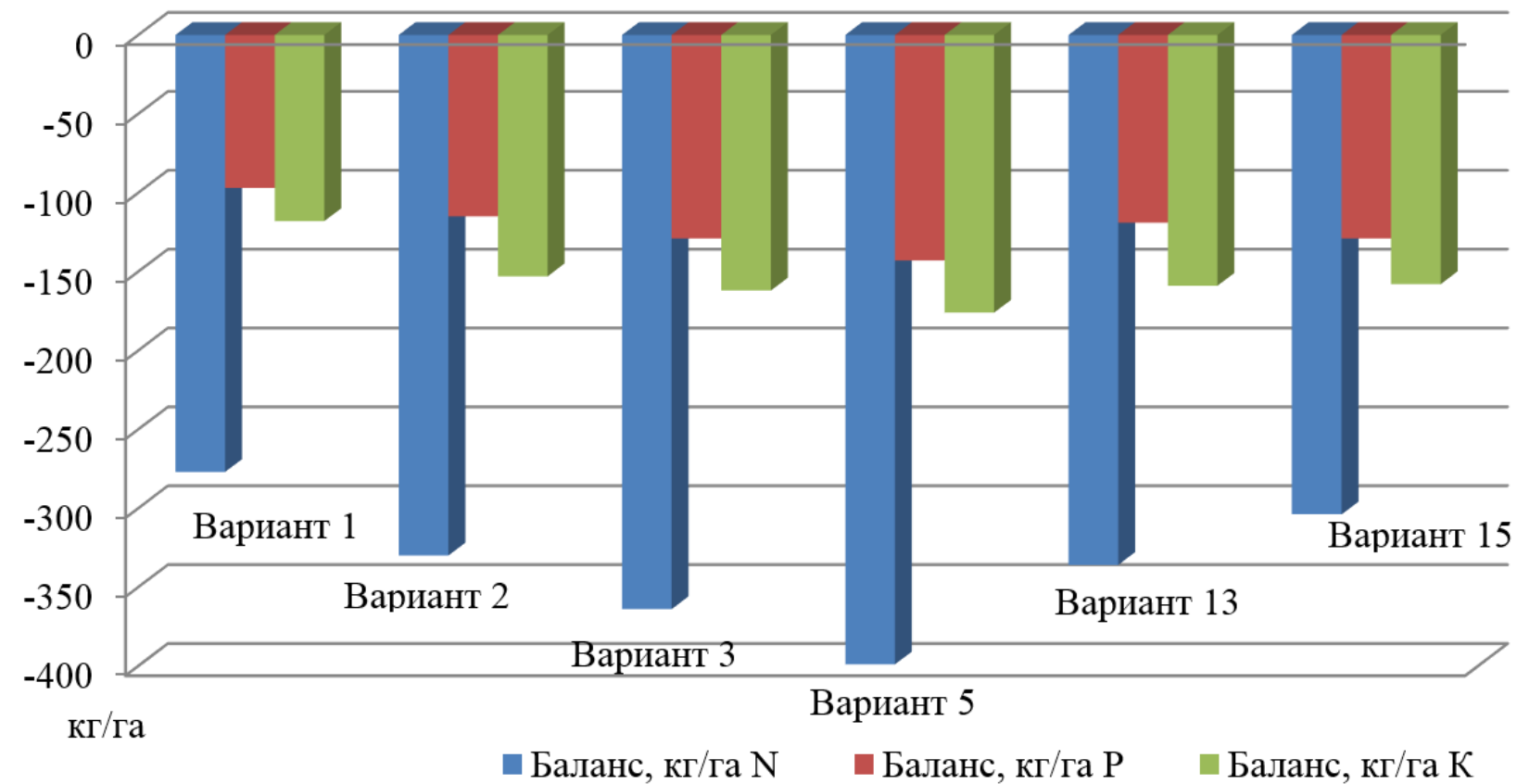

Рис. 2. Баланс элементов питания за ротацию севооборота (кг/га) [3]

Расчет баланса элементов питания показал, что возврат с побочной продукцией составляет: по азоту - 21,3-22,6\%, фосфору - 20,5-22,2\% и калию - 49,5-51,6\%. Из удобренных вариантов наименьший возврат азота и фосфора наблюдается на варианте органоминеральной системы удобрения с двойной дозой минеральных удобрений, а калия - на варианте с органической системой удобрения. На всех вариантах опыта складывается отрицательный баланс по всем элементам питания (рис. 2). Дефицит по азоту составляет 77,4-78,7\%, фосфору - 73,8-79,5\% и калию - 48,4-50,5\%. Как видим, если в органической и органоминеральной системе не достигается даже нулевой баланс элементов питания, то в биологическом земледелии он просто невозможен.

Миф № 3. Выращиванием культур (сидератов), предназначенных для последующей заделки в почву с целью улучшить ее структуру, обогатить ее азотом и подавить рост сорняков, можно обеспечить культурные растения оптимально сбалансированным питанием. Так ли это? Рассмотрим это поподробнее и обоснуем неверность этого утверждения.

Пример: есть участок почвы определенного химического состава, в котором содержится известное количество органики, химических элементов и соединений. Сеем сидераты. Выросшие растения запахали. Вопрос: что добавилось в химическом составе почвы? Ответ - добавились органика и азот. Об азоте чуть позже. Сидераты взяли все химические элементы из почвы, на которой они выросли, а после запашки все вещества в почву и возвратились, то есть взяли в долг и вернули. И только. В почве содержание фосфора, калия и других элементов питания не повысилось даже на миллиграмм. Другое дело, что корневая система сидератов, как биологический насос, перекачала фосфор и калий из нижележащих слоев почвы в верхний слой. Так произошло обогащение верхнего слоя, но в целом в корнеобитаемом слое количество фосфора и калия осталось прежним.

Приверженцы органического земледелия считают, что все бобовые культуры (однолетние и многолетние) обогащают почву азотом. Но не во всех опытах подтверждается факт выделения азотсодержащих соединений из клубеньков в почву. Следует иметь в виду, что ни один вид растений не ставит своей задачей обогащения почвы (субстрата) азотом и/или другими элементами. Ведь в эволюционном развитии бобовые растения «научились» усваивать азот воздуха для того, чтобы выжить в конкурентной борьбе за существование и оставить потомство - семена, в которые и поступает азот из всех органов растений. Зачем же им тратить большое количество энергии (углеводов) для фиксации азота, если не для получения собственного потомства, семян и не более.

На рис. 3 показано перераспределение по органам растения кукурузы по фазам вегетации сухого вещества, азота, фосфора и калия [2].

Как следует из данных рис. 3, к концу вегетации в зерне кукурузы сосредотачивается до 38\% сухого вещества, более $80 \%$ азота и фосфора и до 40\% калия. Воспроизводство - это стратегия всего живого на земле, от микробов до человека. И нет другой, более важной задачи, это стратегия выживания. 

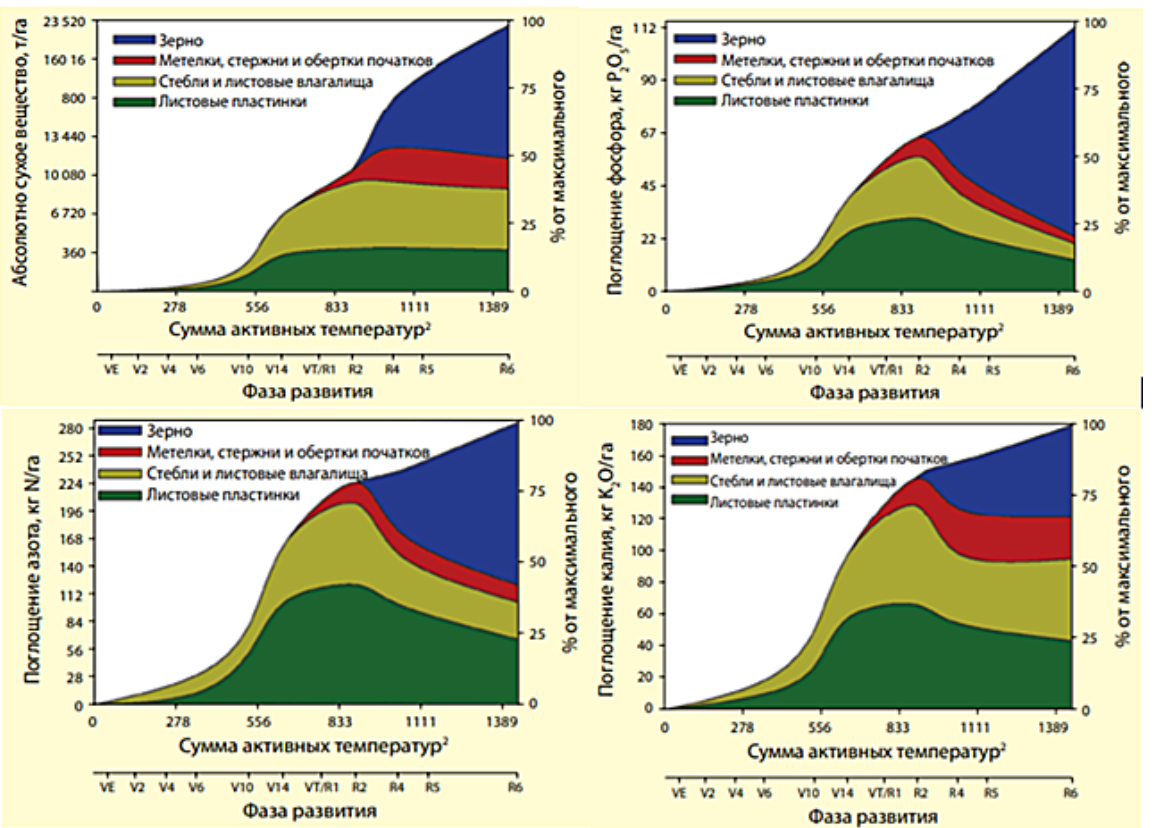

Рис. 3. Перераспределение по органам растения кукурузы по фазам вегетации сухого вещества, азота, фосфора и калия [2]

На фиксацию 1 моля молекул атмосферного азота клубеньковыми бактериями затрачивается 14 молей АТФ, то есть 7 молей глюкозы. А откуда берется эта энергия? Это глюкоза растения-хозяина для симбиотических азотфиксирующих клубеньковых бактерий. Давайте же трезво оценим эти затраты. На синтез 1 кг промышленного аммонийного азота затрачивается 86,6 МДж энергии, а на фиксацию 1 моля атмосферного азота симбиотическими клубеньковыми бактериями затрачивается 14 молей АТФ, то есть 7 молей глюкозы. Вообще-то их требуется 7,5-10 [1, 11]. Но мы проведем расчеты по минимуму, на 7 молей глюкозы. В 1 моле глюкозы (180,16 г) содержится 2881 кДж энергии, а в 7 молях глюкозы (1261,12 г), или 20167 кДж (20,17 МДж). В 1 кг аммонийного азота содержится 55,5 молей, поэтому на синтез 1 моля аммонийного азота расходуется 1,56 МДж энергии. Выходит, что на синтез 1 моля азота симбиотические клубеньковые бактерии затрачивают 20,17 МДж, а технический азот получается при затратах 1,56 МДж, то есть он энергетически в 12,93 раза дешевле!!! Этот процесс необходим для создания полноценных семян и развивается у бобовых растений только при дефиците доступных форм азота и при высоком уровне обеспеченности доступным фосфором и калием, не ниже 4-5 классов, а также подвижного бора и молибдена не ниже средней обеспеченности. При дефиците фосфора, бора и молибдена клубеньки не образуются [1, 11]. Так, может, стоит прекратить фантазии о «даровом» азоте. Ведь 30-50\% продуктов фотосинтеза вместо создания урожая тратится на обеспечение элементами питания растения. И эти затраты на элементы питания для растений вынужденные и обусловлены низким уровнем обеспеченности доступными их формами. Почему же ни у кого не возникает естественный вопрос, чем объяснить низкую урожайность бобовых культур 1,5-3,0 т/га по сравнению с зерновыми - 8-12 т/га? Неужели непонятно, что такова плата бобовых культур за «бесплатный» азот. Так, может, надо перестать говорить о «бесплатном», даровом азоте, на получение которого не тратятся невозобновляемые источники энергии. Напомним, что высокие и стабильные урожаи сельскохозяйственных культур в Европе, США и Канаде достигнуты не рассуждениями, а высокими дозами удобрений.

Напомним приверженцам органического земледелия, что Д.Н. Прянишников четко отметил, в зерновом хозяйстве $\boldsymbol{c}$ урожаем зерна отчуждается больще фосфора, чем с соломой, идущей в навоз (или оставляемой на поверхности поля). Поэтому в зерновом хозяйстве (да в любом) должно происходить постепенное обеднение почвы фосфором [12]. И Д.Н. Прянишников был не первым, выявившим эту закономерность. Этот дефицитный характер круговорота фосфора был выявлен еще Либихом. Он считал, что навоз, как бы тщательно он ни готовился и как бы регулярно им ни удобряли, не может вернуть почве того, чего он сам не содержит, - фосфора зерна (любой основной продукции). Именно поэтому Либих предлагал применять фосфаты для устранения дефицита фосфора.

По этому поводу есть аргументированное мнение Г. Канта: «Бобовые культуры связывают атмосферный азот, но фосфор, калий и кальций в почву не поступают. Поэтому биологическое хозяйство встает перед проблемой пополнения запасов этих питательных элементов путем закупки фосфатов, доломитовой муки, муки из водорослей, томасшлака, а также различного рода отходов». К такому выводу он пришел на основании скрупулезно и добросовестно выполненных исследований более 30 лет назад [5]. Полученные им результаты базируются на круговороте и балансе элементов питания. Это научное исследование, а не призывы о возвращении к Природе. 
Баланс элементов питания в земледелии России [13]

\begin{tabular}{|l|c|c|c|c|c|c|}
\hline \multicolumn{1}{|c|}{ Статьи баланса элементов питания } & $\mathbf{2 0 0 6}$ & $\mathbf{2 0 0 7}$ & $\mathbf{2 0 0 8}$ & $\mathbf{2 0 0 9}$ & $\mathbf{2 0 1 0}$ & $\mathbf{2 0 1 1}$ \\
\hline Внесено элементов питания - всего, млн т д. в. & 3,54 & 3,8 & 4,85 & 4,85 & 4,08 & 4,54 \\
\hline - с минеральными удобрениями & 1,5 & 1,7 & 2,2 & 2,4 & 2,28 & 2,44 \\
\hline - с органическими удобрениями & 0,67 & 0,67 & 0,70 & 0,75 & 0,70 & 0,50 \\
\hline Возврат с соломой и растительными остатками & $1,37 / 15,93 *$ & $1,43 / 15,44$ & $1,95 / 18,22$ & $1,70 / 17,35$ & $1,10 / 15,28$ & $1,60 / 14,81$ \\
\hline Вынос элементов питания, млн т д. в. & 8,6 & 8,7 & 10,7 & 9,8 & 7,2 & 10,8 \\
\hline Баланс элементов питания, млн т д. в. & $-5,0$ & $-4,9$ & $-5,85$ & $-4,95$ & $-3,12$ & $-6,26$ \\
\hline Баланс элементов питания, кг/га посевной площади & $-66,4$ & $-65,6$ & $-76,0$ & $-65,0$ & $-41,0$ & $-84,0$ \\
\hline
\end{tabular}

* - числитель, возврат в млн тонн д. в. (действующего вещества), знаменатель - в \%.

Как можно призывать к отказу от применения удобрений, если баланс элементов питания в почвах России и так уже давно отрицательный (см. табл. 1), и пока что другим он быть не может, потому что наши земледельцы и растениеводы продолжают брать не возвращая. И это притом что по производству минеральных удобрений Россия занимает одно из ведущих мест в мире. Беда в том, что львиная доля удобрений, на производство которых затрачены огромные ресурсы энергии невозобновляемых источников, идет на экспорт. Поднимаем продуктивность зарубежных производителей. Отечественные и так перебьются, дело привычное.

Органическое земледелие предполагает полный отказ от применения минеральных удобрений. Как следует из данных табл. 1, возврат элементов питания с соломой и растительными остатками, как это предполагается делать в органическом земледелии, не превышает 14,81-18,22\%, а дефицит элементов питания соответственно 81,78-85,19\%. Каким образом предполагается покрыть этот воистину дичайший дефицит элементов питания в органическом земледелии? Следствие будет только одно - возрастание дефицита элементов питания и деградация почв, агроистощение. Но у приверженцев органического земледелия есть своеобразная уловка. Полностью отказываясь от применения минеральных удобрений, они допускают применение естественных агроруд. В том числе и фосфатов. В Воронежской области есть залежи фосфатов [8]. В табл. 2 приводим химический состав местных фосфатов и фосфорных удобрений.

Табл. 2

Содержание ТМ в местных фосфатах и в фосфорных удобрениях, мг/кг (валовые формы)

\begin{tabular}{|c|c|c|c|}
\hline Элемент & Фосфаты & Фосфорные удобрения & ПДК \\
\hline As & - & $2-1200$ & 2,0 \\
\hline Cd & 0,75 & $0,1-170$ & 3,0 \\
\hline со & $\mathbf{2 5 , 3}$ & $\mathbf{1 - 1 2}$ & $\mathbf{5 , 0}$ \\
\hline Cr & $\mathbf{7 , 8}$ & $\mathbf{6 5 - 2 4 5}$ & $\mathbf{6 , 0}$ \\
\hline F & $\mathbf{8 , 3}$ & $\mathbf{1 - 3 0 0}$ & 2,0 \\
\hline Hg & - & $8500-38000$ & 2,1 \\
\hline Mn & 0,18 & $0,01-1,2$ & 1000 \\
\hline Mo & 45 & $40-2000$ & - \\
\hline Ni & - & $0,1-60$ & $\mathbf{4 , 0}$ \\
\hline Pb & $\mathbf{1 6 , 2 5}$ & $\mathbf{7 - 3 8}$ & - \\
\hline Se & $\mathbf{2 2}$ & $\mathbf{7 - 2 2 5}$ & 4,5 \\
\hline Sn & - & $0,5-25$ & 23 \\
\hline Zn & - & $3-19$ & \\
\hline
\end{tabular}

Как следует из данных табл. 2, местные фосфаты помимо фосфора содержат и тяжелые металлы (ТМ). Сравнение их с фосфорными удобрениями показывает, что различие заключается только в концентрации ТМ. Ведь минеральные фосфорные удобрения в технологическом цикле подвергаются своеобразному концентрированию для повышения содержания $\mathrm{P}_{2} \mathrm{O}_{5}$. Побочным следствием этого процесса является повышение концентрации ТМ. В местных фосфатах по кобальту, хрому, меди, никелю и свинцу отмечается многократное превыщение ПДК, как и в фосфорных удобрениях. Утверждения приверженцев органического земледелия о безопасности природных руд, как видим, не имеет оснований. Возникает вопрос, почему химический элемент из минерального удобрения опасен, а из природной руды, органического материала, безопасный? Неужели так кардинально меняется природа и свойства химического элемента? Если следовать 
логике апологетов органического земледелия, то это так. Но ведь это уже средневековье и алхимия. Это полное отрицание законов Природы и науки.

Надо все же помнить, что те же воронежские фосфориты содержат 3,5-15\% $\mathrm{P}_{2} \mathrm{O}_{5}$. Это значит, что для внесения средней нормы фосфора 60 кг/га потребуется 150 кг двойного суперфосфата, или 600 кг молотого фосфорита, при среднем содержании $\mathrm{P}_{2} \mathrm{O}_{5}$ 10\%. И не на всех почвах он будет эффективен. Он эффективен только на кислых, то есть деградированных почвах. На этих почвах ТМ более подвижны и, следовательно, доступны растениям и будут в них накапливаться. О какой же тогда «чистоте» продукции может быть речь? И фосфориты надо еще добыть. В Воронежской области мощность фосфоритов колеблется в пределах 0,3-1,5 м, а средняя мощность- 0,2-0,7 м. Более того, они залегают на глубине от 0,6-0,9 м до нескольких десятков метров. И это не голословные утверждения. Наиболее крупным является Хохольское месторождение, расположенное севернее поселка Хохольский. Средняя мощность плиты - 0,48 м. Продуктивность - 633 кг/м², среднее содержание $\mathrm{P}_{2} \mathrm{O}_{5}$ в исходной руде - 6,77\%. Глубина залегания полезной толщи - от 5,0 до 27,0 м [7]. Так ведь после добычи, которая сопровождается нарушением почвенного покрова, фосфориты надо размолоть и доставить производителю.

А вот это уже приведет к удорожанию конечного продукта. Но ведь платить за это будет не производитель, а потребитель, то есть мы с вами. И это благо? Без гарантии безопасности продукта? А ее и не может быть, потому что конечный продукт не подвергается сертификации, а с природным и «безопасным» фосфатом в почву поступают те же ТМ, что и с минеральными удобрениями. Круг замкнулся. Но потребитель этого не знает, поэтому производитель спокоен, спроса с него и ответственности гарантировано не будет.

Вместо исправления катастрофической обстановки в российском земледелии изобретается очередная «волшебная» палочка, одним взмахом которой будут решены все проблемы. Логика, рассудок и здравый смысл не нужны, когда есть указ Президента России. Мы же все помним известные и так любимые ненавистниками России, выдающими себя за патриотов, слова великого поэта России Ф. Тютчева: «...умом Россию не понять, аршином общим не измерить... в Россию можно только верить». То есть все было бы хорошо, беда в том, что Россия с умом несовместима. Блаженны верующие, но ведь когда-то нужно пользоваться и рассудком. Вот тот фон, объективные условия, на которых будет организовано органическое земледелие.

Какой же вывод напрашивается после полученных расчетов? Он прост. Совсем не надо тешить себя мыслями о том, что после бобовых культур в почве может оставаться 150-300 кг/га азота. Надо помнить, что он накапливается в белках бобовых культур и высвобождается после их разложения. Но и после разложения растительных остатков значительная часть азота поглощается микроорганизмами - иммобилизуется. Мобилизация азота микробной массы протекает медленно, за вегетационный период используется всего 30-60\% иммобилизованного азота. Растения, таким образом, смогут использовать от 20 до 40-50 кг/га биологического азота [1]. Так ведь биогенный азот может подвергнуться денитрификации и будет просто потерян.

В органическом земледелии отказ от минеральных удобрений основан на замене азота удобрений фиксацией его из атмосферы бобовыми культурами. При этом фосфор и калий просто выпадают из сферы их внимания. А ведь человечество стоит на пороге катастрофы. Разведанных запасов сырья для получения фосфорных удобрений хватит по самым оптимистичным прогнозам всего на 50 лет. Фосфорная проблема становится куда как актуальней, чем азотная.

И еще одна проблема. Как в органическом земледелии бороться с сорной растительностью, вредителями и болезнями сельскохозяйственных культур? Неужели это возможно биологическими средствами? И это после двух десятилетий интенсивного применения средств химической защиты, когда под их воздействием существенно возросла резистентность новых поколений вредителей и возбудителей болезней. Неужели при нашествии саранчи на органические поля с ней можно будет бороться, посыпая ее табаком?

Миф № 4, и, пожалуй, самый главный - органическое земледелие обеспечит получение экологически «чистой» продукции.

Может ли отказ от применения минеральных удобрений и химических средств защиты растений в течение 3 лет обеспечить получение экологически «чистой» продукции? Мы умышленно взяли в кавычки выражение «чистой», потому что это просто безграмотно. Речь может идти только об экологически безопасной продукции, и это - не игра слов. И еще один вопрос. О качестве питания. Магазины, виноват, маркеты, переполнены продуктами. Неужели в России наступила пора вожделенного изобилия? Но это ведь дважды псевдоизобилие.

Во-первых, это тот редкий случай, когда в России сработал один из рыночных законов - цена продукта и покупательская способность населения. Она бесспорно низкая для большей части населения. Мы уже отмечали, что по урожайности зерновых культур Россия безнадежно и позорно отстает от всех развитых стран, средняя урожайность зерновых в 3-4 раза ниже, чем в Европе. Средний россиянин, живущий за пределами Москвы и Санкт-Петербурга, тратит на питание не менее 30-50\% семейного бюджета.

Во-вторых, какие это продукты? Россия вышла на 1-е место по экспорту зерна. Однако для населения России хлеб пекут из фуражного зерна. Опять же по причине дешевизны и возможности получать высокую прибыль. Новое поколение россиян уже привыкли к тому, что колбаса - это мясо-содержащий продукт, сыр - молоко-содержащий продукт, есть растительные сливки!!! Как это вам? Или творог, в котором животный жир замещен растительным маслом. Этот вопрос 
должен возникнуть у любого человека, посмотревшего состав продукта. Как же так получается, что в составе мясосодержащего продукта, без указания их доли, перечислены такие ингредиенты, как мука, крахмал, белок (чаще всего соевый), мясо птицы и так далее. Ведь они имеют только одно достоинство - дешевизну. Почему же в таком случае продукт, содержащий в основном дешевые, не мясные ингредиенты, дорожсе мяса? Законы рынка не работают?

Жители России превращены в животных третьего сорта по качеству продуктов питания. Корм для кошек содержит более $80 \%$ мясных ингредиентов, корм для собак готовится по старинным семейным рецептам!!! А вот в тушенке для человека содержание жира и мяса составляет 40-50\%, без указания их соотношения. Мало того, в тушеной говядине есть свиная шкура!!! Так может теперь-то уж качество органических продуктов кардинально изменится? А может, Карл Маркс все же был прав? Карлу Марксу принадлежит фраза: «Ради получения 300\% выгоды капиталист зарежет собственную мать». Неужели природа человека настолько изменилась, что современный капиталист устоит перед соблазном получить 500\% прибыли? Автор в это не верит. В стране, где фальсифицируется все и вся, рассчитывать на добросовестность производителей органических продуктов просто несерьезное занятие.

Объявить экологически «чистой» продукцию органического земледелия только на том основании, что не применяются минеральные удобрения, можно. Но где гарантия? Может ли россиянин обратиться в независимую лабораторию и проверить качество продукта? Нет, по причине отсутствия таких лабораторий. А средства массовой информации регулярно сообщают о фальсификации продуктов питания, лекарств и т. д., и т. п. Зададим вопрос, а возможно ли в принципе получить экологически «чистую» продукцию? Ответим - нет. И докажем это.

Теперь о перспективах органического земледелия.

Прежде чем организовывать органическое земледелие, нужно хорошо изучить состав и свойства почв, на которых предполагается внедрять его. А вот достоверных сведений о состоянии наших почв, и прежде всего пашни, в России нет. Как нет и государственной службы, способной это обеспечить. Сведения, которые представляет агрохимическая служба, не могут использоваться для обоснования возможности организации органического земледелия в России. И это прежде всего потому, что изучается только пахотный слой 20-30 см. Но ведь корни растений проникают на глубину 1,5-3 м. Так ведь и мощность преобладающих почв России 2-5 м. Что содержнтся в этой толще - сие тайна великая есть. А ведь состояние земель России назвать благополучным невозможно, если иметь в виду приведенные ниже сведения [10].

Основная площадь земель России 1709,6 млн га, из них пашни - 120 млн га, или 0,89 га на душу населения, при этом:

- 36 млн га пашни подвержены эрозии;

- 2,5 млн га повреждены оврагами;

- 38 млн га переувлажнены;

- 40 млн га засолены;

- 62 млн га загрязнены выбросами промышленных предприятий;

- 1 млн га подвержен техническим разрушениям;

- 3 млн га находятся под свалкой;

- 0,74 млн га превращены в техногенную пустыню;

- 3 млн га загрязнены радионуклидами от аварии в Чернобыле.

Почвы России, мало того что деградированы, они еще и загрязнены - каждый второй гектар (62 млн из 120 млн га). Как на них можно получать экологически «чистую» продукцию? Ведь законы биологии никто не отменял. Надо все же помнить о существовании трофической цепи и о законах превращения вещества и энергии, наконец, о биогенной аккумуляции:
Почва
Растение
$\rightarrow$
Животное
X. э. $-\mathbf{0 , 1 \%}$
Человек
X. э. $-0,01 \%$
Х. э. $-1,0 \%$

Представим, что в почве содержится какой-то химический элемент в указанном выше количестве $(0,001 \%)$. Растение, избирательно поглощая этот элемент, повышает его концентрацию на порядок. Растительная продукция используется на корм животным, и в теле животного концентрация элемента повышается еще на порядок. Если даже остановиться на этом звене, то концентрация химического элемента в животном и его навозе будет в 100 раз выше, чем в почве.

По данным табл. 3 в живых организмах аккумулируются 37 химических элементов, в том числе и тяжелые металлы. Они неминуемо поступают в живые организмы, включая человека (см. табл. 3), потому что необходимы для нормального развития. О какой же тогда «чистоте» может быть речь? Ежедневно с пищей в организм человека должно поступать 17 химических элементов (см. табл. 4) [9], и тяжелые металлы тоже (см. трофическую цепь).

Поэтому надо прекратить врать; не надо позориться обещаниями невозможного. Экологическая «чистота» невозможна, речь может быть только об экологически безопасной продукции. Учитывая все выше изложенное, следует, по крайней мере, усомниться в возможности получения таковой продукции. 
Средний элементный состав живого вещества, \% живого веса по Виноградову [4]

\begin{tabular}{|c|c|c|}
\hline Группа & Содержание, \% & Химические элементы \\
\hline \multirow{3}{*}{ Макроэлементы } & $10^{1}$ & $\mathrm{O}, \mathrm{H}$ \\
\cline { 2 - 3 } & $10^{0}-10^{1}$ & $\mathrm{C}, \mathrm{N}, \mathrm{Ca}$ \\
\cline { 2 - 3 } & $10^{-1}-10^{0}$ & $\mathrm{~S}, \mathrm{P}, \mathrm{K}, \mathrm{Si}$ \\
\cline { 2 - 3 } & $10^{-2}-10^{-1}$ & $\mathrm{Mg}, \mathrm{Fe}, \mathrm{Na}, \mathrm{Cl}, \mathrm{Al}$ \\
\hline \multirow{2}{*}{ Микроэлементы } & $10^{-3}-10^{-2}$ & $\mathrm{Zn}, \mathrm{Br}, \mathrm{Mn}, \mathrm{Cu}$ \\
\cline { 2 - 3 } & $10^{-4}-10^{-3}$ & $\mathrm{Jg}, \mathrm{As}, \mathrm{B}, \mathrm{F}, \mathrm{Pb}, \mathrm{Ti}, \mathrm{Va}, \mathrm{Cr}, \mathrm{Ni}, \mathrm{Sr}$ \\
\hline \multirow{3}{*}{ Ультраэлементы } & $10^{-5}-10^{-4}$ & $\mathrm{Au}, \mathrm{Rb}$ \\
\cline { 2 - 3 } & $10^{-5}-10^{-6}$ & $\mathrm{Hg}, \mathrm{U}$ \\
\cline { 2 - 3 } & $10^{-11}-10^{-6}$ & $\mathrm{Ra}$ \\
\cline { 2 - 3 } & $10^{-12}-10^{-11}$ & \\
\hline
\end{tabular}

Табл. 4

Суточное поступление химических элементов в организм человека (по Ю.Н. Кукушкину, 1998 [9])

\begin{tabular}{|c|c|c|c|c|c|}
\hline Элемент & Взрослые & Дети & Элемент & Взрослые & Дети \\
\hline $\mathrm{K}$ & $2000-5500$ & 530 & $\mathrm{Cr}$ & $0,05-0,2$ & 0,04 \\
\hline $\mathrm{Na}$ & $1100-3300$ & 260 & $\mathrm{Co}$ & $\begin{array}{c}\text { Около 0,2 } \\
\left.\text { (витамин } \mathrm{B}_{12}\right)\end{array}$ & 0,001 \\
\hline $\mathrm{Ca}$ & $800-1200$ & 420 & & 3200 & 470 \\
\hline $\mathrm{Mg}$ & $300-400$ & 60 & $\mathrm{Cl}$ & $800-1200$ & 210 \\
\hline $\mathrm{Zn}$ & 15 & 5 & $\mathrm{P}_{2} \mathrm{O}_{5}$ & 10 & - \\
\hline $\mathrm{Fe}$ & $10-15$ & 7 & $\mathrm{SO}_{4}{ }^{-2}$ & 0,15 & 0,07 \\
\hline $\mathrm{Mn}$ & $2,0-5,0$ & 1,3 & $\mathrm{I}$ & $0,05-0,07$ & - \\
\hline $\mathrm{Cu}$ & $1,5-3,0$ & 1 & $\mathrm{Se}$ & $1,5-4,0$ & 0,6 \\
\hline $\mathrm{Mo}$ & $0,075-0,250$ & 0,06 & $\mathrm{~F}$ & & \\
\hline
\end{tabular}

Миф № 5 - обеспечить изобилие продуктов высокого качества.

И это тоже недостижимо по простой причине, которая изложена в самом начале работы. Продуктивность пашни России остается в несколько раз ниже, чем в развитых странах. Органическое земледелие, в том виде, как оно пропагандируется, может только усугубить ситуацию.

Дороговизна органических продуктов делает их недоступными для широких слоев населения. Это общеизвестный факт. Так что, России опять угрожает голод? И вновь нас ждет голод организованный, по благородным побуждениям, это такая забота о здоровье людей?

Таким образом, выгодный проект с экологически «чистым» питанием постепенно завоевывает планету. Автор недаром выделил особенность экологического питания. Экологическая Афера, именуемая «органическим земледелием», товар, как мы уже показали, забугорный. В обмен на внедрение у нас отсталого, неэффективного сельхозпроизводства Запад вывозит из России 90\% наших минеральных удобрений.

И последнее. Казалось бы, при отказе от применения дорогих минеральных удобрений и средств защиты растений должны бы снизиться затраты на производство органической продукции. Но они оказываются наоборот выше, почему? Ответ понятен. Высокая стоимость продукции органического земледелия призвана компенсировать его низкую продуктивность. Это только в интересах производителя, и это - полное игнорирование интересов массового потребителя. В таком случае в России вновь сработает закон рынка - несоответствие цен на продукты покупательской способности населения. Он ведь уже работает в России, не признавать это просто глупо.

Сохранение почв, основного национального достояния, - главнейшая задача государства и людей, в нем живущих. А сохраним ли мы их при таком отношении, когда игнорируются законы Природы, но остаются только призывы к ее сохранению и копированию?

Нам, почвоведам, понятна озабоченность И.А. Крупеникова судьбой чернозема: «Моя научная жизнь, особенно с середины прошлого века, тесно и на многие годы связала меня с черноземом... Наблюдая его в течение 70 лет в разных регионах Евразии, особенно в Молдове, я с сожалением, даже горечью, должен признать, что на моих глазах чернозем за эти десятилетия очень много потерял: утратил во многом свою силу, мощь и красоту, перестал щедро вознаграждать труд 
землепашца, экологически и экономически оскудел... Жаль до слез, если люди в конце нашего века уничтожат это великое, неповторимое чудо природы - чернозем - такой красивый среди почв, вековечный кормилец» [8]. Уже уничтожили.

\section{Список русскоязычной литературы}

\section{ЛИТЕРАТУРА}

1. Бабьева ИП, Зенова ГМ. Биология почв. М.: Изд-во МГУ, 1982.

2. Бендер РР, Хаегеле ДжВ, Руффо МЛ, Белоу ФЕ. Динамика поглощения элементов питания современными гибридами кукурузы. URL: http://eeca-ru.ipni.net/article/EECARU-2231.

3. Верзилина НД, Стекольников КЕ. Проблемы органического земледелия в ЦЧР. В кн.: Биологизация земледелия: перспективы и реальные возможности. Воронеж; 2019. С. 45-56.

4. Виноградов АП. Геохимия редких и рассеянных химических элементов в почвах. М.: Изд-во АН СССР; 1957.

5. Кант Г. Биологическое растениеводство: возможности биологических агросистем. М.: Агропромиздат; 1988.

6. Коршунов СА, Любоведская АА, Асатурова АМ, Исмаилов ВЯ, Коноваленко ЛЮ. Органическое сельское хозяйство: инновационные технологии, опыт, перспективы: научно-аналитический обзор. М.: Росинформагротех; 2019.

7. Крайнов АВ, Горюшкин ВВ. Фосфориты района Латненского месторождения (Воронежская область). Возможности использования. Вестник ВГУ Сер Геол. 2017;(3):24-9.

8. Крупеников ИА. Черноземы. Возникновение, совершенство, трагедия деградации, пути охраны и возрождения. Кишинев: Pontos; 2008.

9. Кукушкин ЮН. Химические элементы в организме человека. Соросовский образовательный журнал. 1998;(5):54-8.

10. Лойко ПФ. Земельный потенциал мира и России: пути глобализации его использования в XXI веке. М.: Федеральный кадастровый центр «Земля»; 2000.

11. Пейве ЯВ. Биохимия почв. М.: Гос. Изд-во с.-х. литературы, журналов и плакатов; 1961.

12. Прянишников ДН. Агрохимия. М.: Сельхозгиз; 1934.

13. Чекмарев ПА. Состояние плодородия почв и мероприятия по его повышению в 2012 г. Агрохимический вестник. 2012;(1):2-4.

\section{Общий список литературы/Reference list}

1. Babyeva IP, Zenova GM. Biologiya Pochv. Moskow: MGU; 1982. (In Russ.)

2. Bender RR, Haegele JW, Ruffo ML, Below FE. Nutrient uptake, partitioning, and remobilization in modern, transgenic insectprotected maize hybrids. Agronomy J., 2013;105:161-70. doi:10.2134/agronj2012.0352

3. Verzilina ND, Stekolnikov KYe. [Problems of organic agriculture in the Central Chernozem Region]. In: Biologizatsiya Zemledeliya Perspektivy i Realnye Vozmozhnosti. Voronezh; 2019. P. 45-56. (In Russ.)

4. Vinogradov AP. Geokhimiya Redkikh i Rasseyannykh Khimicheskikh Elementov v Pochvakh. Moscow: Izd-vo AN SSSR; 1957. (In Russ.)

5. Kant G. Biologicheskoye Rasteniyevodstvo Vosmozhnosti Biologicheskikh Agrosistem. Moscow: Agropromizdat; 1988. (In Russ.)

6. Korshunov SA, Liubovedskaya AA, Asaturova AM, Ismailov VYa, Konovalenko LYu. Organicheskoye Selskoye Khoziaystrvo: Innovatsionnye Tekhnologii, Opyt, Perspectivy: Nauchno-Analyticheskiy Obzor. Moscow: Rosinformagrotekh; 2019. (In Russ.)

7. Kraynov AB, Goriushin VV. [Phorphorites of Latnenskiy deposit (Voronezhskaya Oblast). Possibilities for their exploitation]. Vestnik VGU Ser Geol. 2017;(3):24-9. (In Russ.)

8. Krupenikov IA. Chernozemy. Vozniknovemiye, Sovershenstvo, Tragediya Degradatsii, Puti Okhrany i Vosrozhdeniya. Chişinău: Pontos; 2008. (In Russ.)

9. Kukushkin YuN. [Chemical elements in human body]. Sorosovskiy Obrazovatelnyi Zhusnal. 1998;(5):54-8. (In Russ.)

10. Loyko PF. Zemelnyi Potentsial Mira i Rossii: Puti Gloibalozatsii Yego Ispolzovaniya v XXI Veke. Moscow: Federalnyi Kadastrovyi Tsentr "Zemlia”; 2000. (In Russ.)

11. Peyve YaV. Biokhimiya Pochv. Moscow: Izdatelstvo Selskokhoziaystvennoy Literatuty, Zgurnalov i Plakatov; 1961. (In Russ.)

12. Prianishnikov DN. Agrokhimiya. Moscow: Selkhozgiz; 1934. (In Russ.)

13. Chekmarev PA. [The conditions of soil fertility and the measures aimed to increase it in 2012]. Agrokhimicheskiy Vestnik. 2012;(1)2-4. (In Russ.)

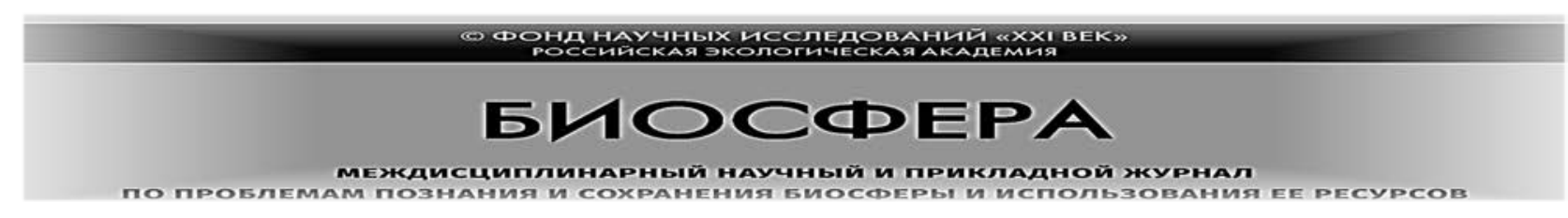

